\title{
ANALISIS PERBANDINGAN KINERJA ALGORITMA BLOWFISH DAN ALGORITMA TWOFISH PADA PROSES ENKRIPSI DAN DEKRIPSI
}

\author{
Dimas Aulia Trianggana ${ }^{1}$, Herlina Latipa Sari ${ }^{2}$ \\ 1,2Program Studi Teknik Informatika - S1, Fakultas Ilmu Komputer \\ Universitas Dehasen Bengkulu \\ ${ }^{1}$ ezdroez@gmail.com \\ ${ }^{2}$ herlinalatipasari@ymail.com
}

\begin{abstract}
Abstrak: Algoritma Blowfish dan algoritma Twofish merupakan dua buah algoritma kriptografi yang bersifat simetris dan beroperasi dalam bentuk blok cipher, jaringan fiestel, dan s-box. Berdasarkan hal tersebut, timbul suatu permasalahan antara algoritma Blowfish dan Twofish terhadap estimasi waktu yang diperlukan pada saat proses enkripsi dan dekripsi suatu file. Penelitian ini bertujuan untuk menganalisis kedua algoritma tersebut, dan mengujinya dengan cara membuat sebuah aplikasi berbasis windows yang dapat digunakan untuk mengukur estimasi waktu proses dan besar file setelah proses enkripsi dan dekripsi, sehingga dapat dilakukan perbandingan antara kedua algoritma tersebut. Pengujian dilakukan menggunakan file dokumen dengan extension *.doc, *.xls, *.psd, *.ppt baik untuk proses enkripsi maupun dekripsi. Dari hasil pengujian yang telah dilakukan diperoleh hasil bahwa jika ditinjau dari estimasi waktu proses enkripsi dan dekripsi, algoritma Blowfish lebih cepat waktu eksekusinya dibandingkan dengan algoritma Twofish, dan jika ditinjau dari besar ukuran file sebelum dan sesudah proses enkripsi dan dekripsi, algoritma Blowfish dan algoritma Twofish memiliki besar ukuran yang sama. Kata Kunci : Kriptografi, Algoritma Blowfish, Algoritma Twofish.
\end{abstract}

Abstract: Blowfish algorithm and Twofish algorithm are two symmetrical cryptographic algorithms. They operate block ciphers, fiestel network, and s-box. Based on this, we need to estimate the time required during the process of encryption and decryption of a file. This research aims to analyze both of the algorithm by making a window based application that can measure the time and size of files after encryption and decryption process. The system was tested using files with the following extensions * .doc, *.xls, * .psd, * .ppt. Experiments results that Blowfish algorithm is faster than Twofish, with similar in size between Twofish and Blowfish both before and after the process of encryption and decryption.

Keywords: Cryptography, Blowfish Algorithm, Twofish algorithm.

\section{PENDAHULUAN}

1.1 Latar Belakang

Kriptografi

(Cryptography)

didefinisikan sebagai ilmu sekaligus seni untuk menjaga kerahasiaan pesan (data atau informasi) yang mempunyai pengertian, dengan cara menyamarkannya (mengacak) menjadi bentuk yang tidak dapa dimengerti menggunakan suatu algoritma tertentu.

Algoritma kriptografi terbagi dalam algoritma klasik dan modern. Contoh dari algoritma klasik adalah Caesar cipher, sedangkan contoh dari algoritma modern adalah algoritma Blowfish dan Twofish. Algoritma Blowfish dan algoritma Twofish telah banyak diterapkan untuk keamanan data, yakni pada enkripsi pesan suara, proses $e$ banking, komunikasi jaringan seluler, dan lain-lain. Kedua algoritma tersebut memiliki beberapa kesamaan, yaitu sama-sama menggunakan kunci simetris, cipher blok, jaringan fiestel, dan s-box.

Berdasarkan hal tersebut, timbul suatu permasalahan antara algoritma Blowfish dan Twofish terhadap pengukuran performansi waktu serta efektifitas (ukuran file) sebagai hasil proses enkripsi dan dekripsi suatu file. 
1.2 Rumusan Masalah

1. Bagaimana membangun aplikasi kriptografi untuk membandingkan kinerja algoritma Blowfish dan algoritma Twofish ?

2. Bagaimana langkah-langkah dalam proses enkripsi dan dekripsi pada algoritma Blowfish dan algoritma Twofish?

3. Bagaimana mengananalisis perbandingan kinerja dari algoritma Blowfish dan algoritma Twofish dalam proses enkripsi dan dekripsi ?

\subsection{Batasan Masalah}

1. Membahas hanya mengenai algoritma Blowfish dan algoritma Twofish pada proses enkripsi dan dekripsi.

2. Pembangunan aplikasi digunakan untuk menganalisis perbandingan kinerja dalam hal estimasi waktu proses enkripsi dan dekripsi, besar ukuran file sebelum dan sesudah proses enkripsi dan dekripsi dilakukan, serta kecepatan proses enkripsi dan dekripsi.

3. File yang akan diuji untuk keperluan analisis perbandingan adalah file dokumen extention *.doc, *.xls, *.psd, *.ppt. Sistem ini dibangun menggunakan Visual Basic 6.0 dan berbasis Windows.

\section{LANDASAN TEORI}

\subsection{Algoritma Blowfish}

Blowfish merupakan enkripsi yang menggunakan algoritma simetris yang tergolong ke dalam algoritma cipher blok. Blowfish dirancang untuk memenuhi kriteria sebagai berikut :

1. Cepat, pada implementasi yang optimal Blowfish dapat mencapai kecepatan 26 clock cycle/byte

2. Kompak, Blowfish dapat berjalan pada memori kurang dari $5 \mathrm{~KB}$
3. Sederhana, Blowfish hanya menggunakan operasi yang sederhana, yaitu penambahan (addition), XOR, dan penelusuran tabel (table lookup) pada operand 32 bit

4. Keamanan yang variabel, panjang kunci Blowfish dapat bervariasi dan dapat mencapai 448 bit (56 Byte)

Algoritma Blowfish menggunakan kunci yang sama untuk proses enkripsi dan dekripsi data dengan membagi pesan ke dalam blok-blok dengan ukuran yang sama panjang [5].

Blowfish termasuk dalam enkripsi block cipher 64 bit dengan panjang kunci antara 32 bit sampai 448 bit. Algoritma Blowfish terdiri atas dua bagian, yaitu [6]:

\section{Key-Expansion}

Berfungsi merubah kunci (Minimum 32-bit, Maksimum 448-bit) menjadi beberapa array subkunci (subkey) dengan total 4168 byte.

\section{Enkripsi Data}

Terdiri dari iterasi fungsi sederhana (feistel Network) sebanyak 16 kali putaran. Setiap putaran terdiri dari permutasi kunci-dependent dan substitusi kunci- dan data-dependent. Semua operasi adalah penambahan (addition) dan XOR pada variabel 32-bit. Operasi tambahan lainnya hanyalah empat penelusuran tabel (table lookup) array berindeks untuk setiap putaran

Pada algoritma Blowfish, digunakan banyak subkey. Kunci-kunci ini harus dihitung atau dibangkitkan terlebih dahulu sebelum dilakukan enkripsi atau dekripsi data. Pada jaringan feistel, Blowfish memiliki 16 iterasi, masukannya adalah 64 bit elemen data atau sebut saja “ $X$ ”[7].

Adapun alur algoritma enkripsi dengan metoda Blowfish dijelaskan sebagai berikut [5] :

1. Bentuk inisial P-array sebanyak 18 buah $\left(P_{0}, P_{1}, \ldots \ldots \ldots \ldots . . . P_{17}\right)$ masing-masing bernilai 32- 
bit. Array P terdiri dari delapan belas kunci 32bit subkunci $P_{0}, P_{1}, \ldots \ldots ., P_{17}$

2. Bentuk $S$-box sebanyak 4 buah masing-masing bernilai 32-bit yang memiliki masukan 256. Empat 32-bit S-box masing-masing mempunyai 256 masukan:

\begin{tabular}{|c|}
\hline$S_{1,0}, S_{1,1}, \ldots \ldots \ldots \ldots \ldots \ldots \ldots, S_{1,255}$ \\
\hline$S_{2,0}, S_{2,1}, \ldots \ldots \ldots \ldots \ldots \ldots, S_{2,255}$ \\
\hline$S_{3,0}, S_{3,1}, \ldots \ldots \ldots \ldots \ldots \ldots, S_{3,255}$ \\
\hline$S_{4,0}, S_{4,1}$, \\
\hline
\end{tabular}

3. Plaintext yang akan dienkripsi diasumsikan sebagai masukan, Plaintext tersebut diambil sebanyak 64-bit, dan apabila kurang dari 64-bit maka kita tambahkan bit-nya, supaya dalam operasi nanti sesuai dengan datanya.

4. Hasil pengambilan tadi dibagi 2, 32-bit pertama disebut $X L$, 32-bit yang kedua disebut $X R$.

5. Selanjutnya lakukan operasi $X L=X L$ xor $P i$ dan $X R=F(X L)$ xor $X R$

6. Hasil dari operrasi diatas ditukar $X L$ menjadi $X R$ dan $X R$ menjadi $X L$.

7. Lakukan sebanyak 16 kali, perulangan yang ke16 lakukan lagi proses penukaran $X L$ dan $X R$.

8. Pada proses ke-17 lakukan operasi untuk $X R=$ $X R$ xor $P_{16}$ dan $X L=X L$ xor $P_{17}$.

9. Proses terakhir, satukan kembali $X L$ dan $X R$ sehingga menjadi 64-bit kembali.

\subsection{Algoritma Twofish}

Twofish adalah algoritma kriptografi yang beroperasi dalam mode block cipher. Twofish menjadi salah satu finalis dalam kompetisi Advanced Encryption Standar (AES) yang diadakan oleh National Institute of Standars and Technology (NIST). Twofish adalah block cipher yang berukuran 128 bit yang dapat menerima kunci dengan panjang mencapai 256 bit.

Tahapan-tahapan pada algoritma Twofish lebih jelasnya adalah sebagai berikut :
1. Bit masukan disebut sebagai $P_{0}, P_{1}, P_{2}$, dan $P_{3}$. $P_{0}$ dan $P_{1}$ akan menjadi bagian kiri, dua lainnya akan menjadi masukan pada bagian kanan.

2. Kemudian akan melalui proses whitening.

3. Bagian kiri akan menjadi masukan untuk fungsi $f, P_{0}$ akan langsung menjadi masukan bagi fungsi $g$, sementara $P_{1}$ akan di-rotate 8 bit sebelum diproses oleh fungsi $g$.

4. Didalam fungsi $g$, bit-bit tersebut akan melalui S-box dan matriks MDS, kemudian kedua keluaran akan digabungkan oleh PHT.

5. Setelah melalui PHT, kedua bagian tersebut akan ditambah dengan bagian dari kunci sesuai dengan iterasi yang telah dilewati. Untuk keluaran dari fungsi $f$ dengan input $P_{1}$ akan ditambah dengan $K_{2 r+8}$. Untuk keluaran dari fungsi $f$ dengan input $P_{1}$ akan ditambah dengan $K_{2 r+9}$, dimana $r$ adalah jumlah iterasi yang telah dilewati. Masing-masing ditambah delapan dan sembilan karena delapan urutan awal sudah digunakan untuk whitening input dan output.

6. Keluaran dari fungsi $f$ dengan input $P_{0}$ akan di$X O R$ dengan $P_{2}$, kemudian hasil $X O R$ tersebut akan di-rotate 1 bit.

7. Keluaran dari fungsi $f$ dengan input $P_{1}$ akan diXOR dengan $P_{3}$, namun $P_{3}$ sebelumnya dirotate 1 bit terlebih dahulu.

8. Setelah perhitungan bit selesai, bagian kanan yang telah dihitung tadi akan menjadi bagian kiri dan bagian kiri yang belum dihitung akan menjadi bagian kanan.

9. Kemudian setelah 16 iterasi, akan dilakukan whitening terhadap keluarannya. Whitening pada output akan meng-undo pertukaran bagian kanan dan bagian kiri pada iterasi terakhir, dan melakukan XOR data dengan 4 bagian kunci,

$$
C i=R 16,_{(i+2) \bmod 4} \oplus K_{i+4} i=0, \ldots, 3
$$

Bagian kunci yang digunakan disini berbeda dengan bagian kunci yang akan digunakan saat 
whitening pada input. Oleh karena itu urutan bagian kunci yang dipakai ditambah empat, karena empat urutan bagian kunci satu sampai empat sudah terlebih dahulu digunakan untuk whitening pada input.

10. Keempat bagian cipherteks tersebut kemudian ditulis menjadi 16 byte $C_{0}, \ldots, C_{15}$ menggunakan konversi little-endian seperti pada plainteks.

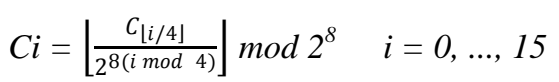

\section{METODE PENELITIAN}

\subsection{Kerangka Kerja}

1. Identifikasi Masalah

2. Studi Pustaka

3. Analisis Sistem

Pada tahapan ini dilakukan analisis terhadap kebutuhan sistem, serta menganalisis elemenelemen yang dibutuhkan oleh sistem. Pada tahap ini dilakukan studi terhadap sistem kerja algoritma Blowfish dan Twofish yang didapatkan.

4. Perancangan

Pada tahapan ini dilakukan perancangan tampilan program yang akan dibuat penulis. Tampilan program bersifat user-friendly atau mudah digunakan oleh pengguna.

5. Implementasi

Tahapan ini dilakukan untuk mengimplementasikan hasil rancangan dan analisis di atas. Pada tahapan ini dilakukan pembuatan program, pembuatan antarmuka masukan dan keluaran, dan antarmuka proses enkripsi dan dekripsi algoritma Blowfish dan algoritma Twofish.
6. Pengujian

Pada tahap ini penulis melakukan pengujian terhadap algoritma Blowfish dan Twofish dengan menggunakan aplikasi kriptografi. Adapun mekanisme pengujiannya yaitu :

a. Mempersiapkan file-file yang akan diuji, yaitu file dokumen dengan extention *.doc, *.xls, *.psd, *.ppt.

b. Menetapkan kunci untuk proses enkripsi dan dekripsi. Karena algoritma Blowfish dan Twofish merupakan kunci simetris, maka kunci yang digunakan adalah kunci yang sama dalam proses enkripsi dan dekripsi

c. Melakukan proses enkripsi setiap file asli yang akan diuji dengan kunci yang telah ditetapkan. Kemudian mencatat waktu proses enkripsi, dan kapasitas file sebelum dan sesudah proses enkripsi dilakukan.

d. Melakukan proses dekripsi setiap file hasil enkripsi dengan kunci yang telah ditetapkan (kunci yang sama dengan kunci yang digunakan dalam proses enkripsi). Kemudian mencatat waktu proses dekripsi, dan kapasitas file sebelum dan sesudah proses dekripsi dilakukan, menghitung kecepatan proses enkripsi dan dekripsi.

e. Hasil proses enkripsi dan dekripsi yang telah dicatat tadi kemudian di analisis kembali untuk memberikan perbandingan kinerja antara algoritma Blowfish dan algoritma Twofish, sehingga nantinya diperoleh kesimpulan tentang kelebihan dan kekurangan antara kedua algoritma tersebut.

\section{Dokumentasi}

Dilakukan dokumentasi laporan mulai dari identifikasi masalah hingga implementasi dan pengujian. 
3.2. Skema Proses Enkripsi dan Dekripsi Algoritma Blowfish

Algoritma Blowfish menggunakan kunci simetris dalam proses enkripsi dan dekripsi. Misalkan kunci yang digunakan untuk proses

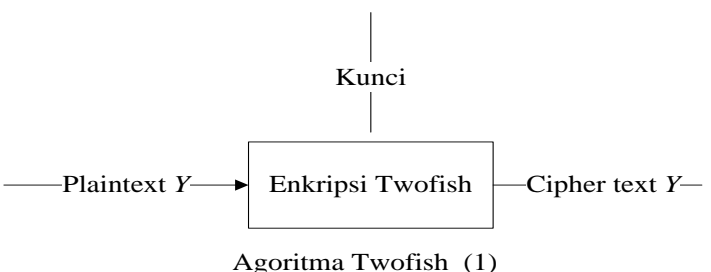
enkripsi adalah 123. Maka untuk melakukan dekripsi harus menggunakan kunci yang sama yaitu 123, agar didapati hasil yang sama sebelum dienkripsi. Adapun skema proses enkripsi dan dekripsi pada algoritma Blowfish, dapat di lihat pada gambar 1 .

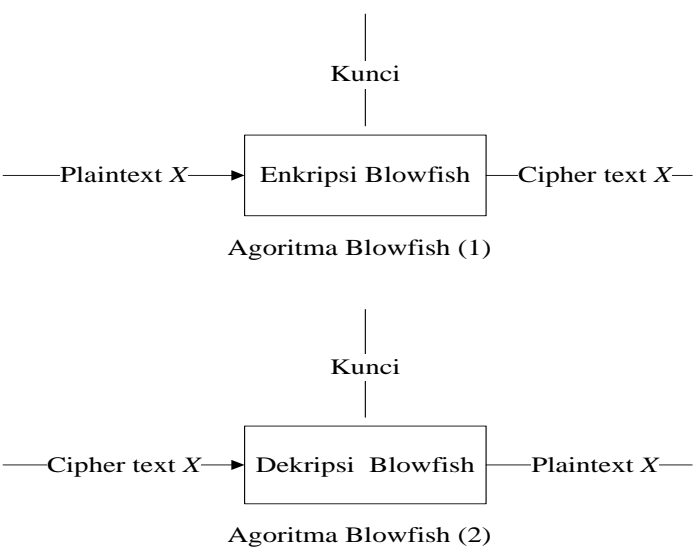

Gambar 1. Skema Proses Enkripsi dan Dekripsi Algoritma Blowfish

3.3. Skema Proses Enkripsi dan Dekripsi Algoritma Twofish

Algoritma Twofish menggunakan kunci simetris dalam proses enkripsi dan dekripsi. Misalkan kunci yang digunakan untuk proses enkripsi adalah 123. Maka untuk melakukan dekripsi harus menggunakan kunci yang sama yaitu 123, agar didapati hasil yang sama sebelum dienkripsi. Adapun skema proses enkripsi dan dekripsi pada algoritma Twofish, dapat di lihat pada gambar 2 .

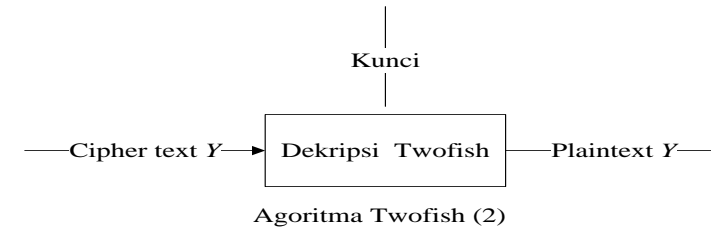

Gambar 2. Skema Proses Enkripsi dan Dekripsi Algoritma Twofish

\section{IV.HASIL DAN PEMBAHASAN}

\subsection{Implementasi Sistem}

Antarmuka perangkat lunak dibuat menggunakan IDE Visual Basic 6.0, yang memiliki kelas-kelas dan modul untuk membuat Graphical User Interface (GUI). Antarmuka perangkat lunak kriptografi terbagi menjadi 4 (empat) menu, yaitu sebagai berikut :

\section{Menu Utama}

Menu utama merupakan menu yang pertama kali tampil ketika program dijalankan oleh pengguna.

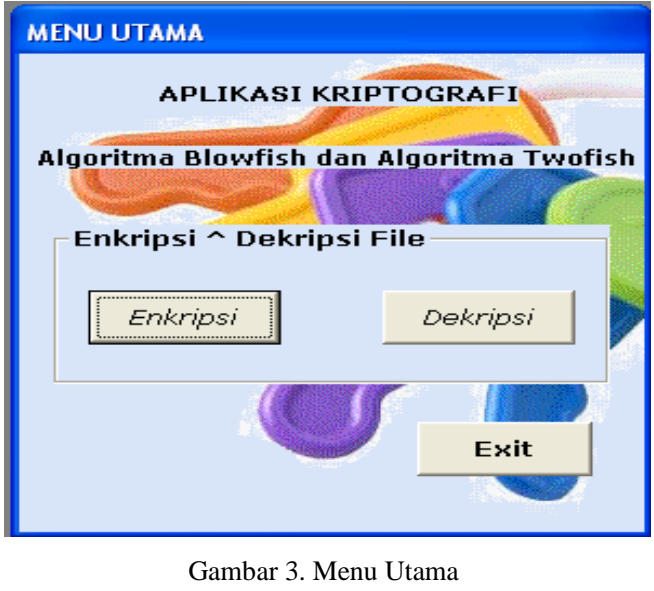

\section{Menu Enkripsi File}

Menu enkripsi file merupakan menu yang akan digunakan untuk melakukan proses enkripsi file pada algoritma Blowfish dan algoritma Twofish. 


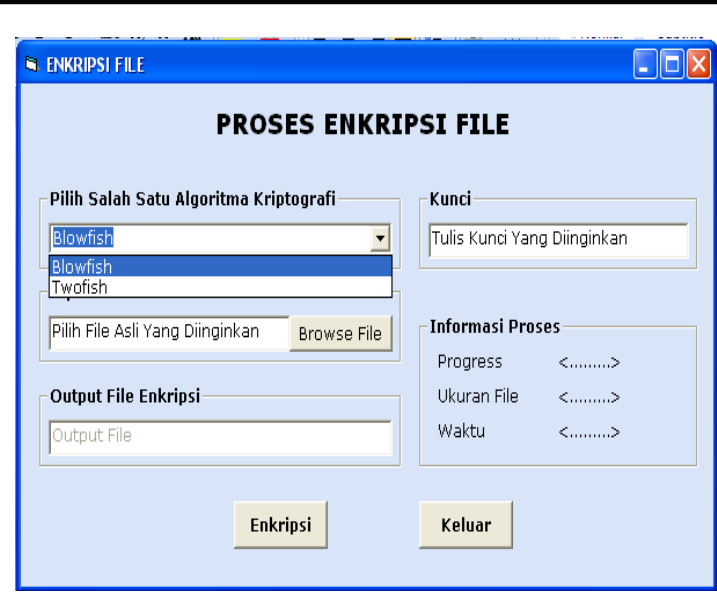

Gambar 4. Menu Enkripsi File

\section{Menu Dekripsi File}

Menu dekripsi file merupakan menu yang akan digunakan untuk melakukan proses dekripsi file pada algoritma Blowfish dan algoritma Twofish.

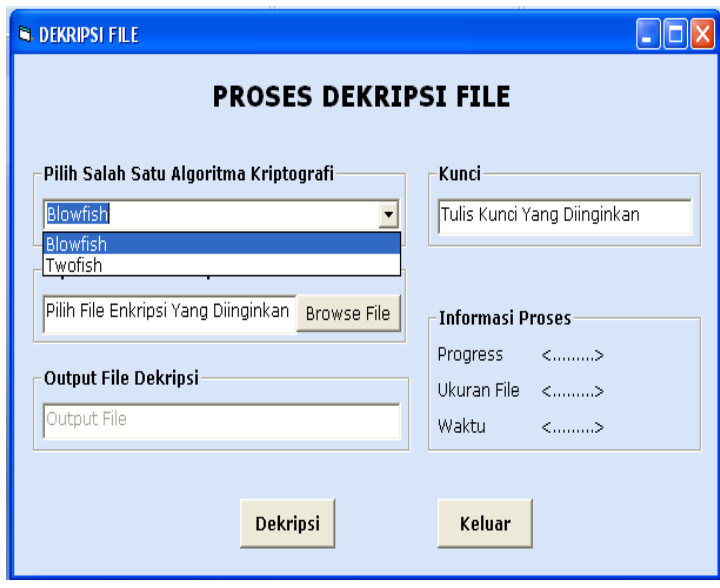

Gambar 5. Menu Dekripsi File

\subsection{Pengujian Sistem}

Pada tahap ini, penulis melakukan pengujian perangkat lunak menggunakan algoritma Blowfish dalam proses enkripsi dan dekripsi file yang telah disiapkan pada skenario pengujian.

Tabel 1. Hasil Proses Enkripsi File Algoritma Blowfish

\begin{tabular}{|c|l|c|l|l|l|}
\hline \multirow{2}{*}{ No } & \multicolumn{2}{|c|}{ File Asli } & \multicolumn{2}{c|}{$\begin{array}{c}\text { File Hasil } \\
\text { Enkripsi }\end{array}$} & $\begin{array}{c}\text { Waktu } \\
\text { Proses } \\
\text { (ms) }\end{array}$ \\
\cline { 2 - 5 } & $\begin{array}{l}\text { Nama } \\
\text { File }\end{array}$ & $\begin{array}{c}\text { Size } \\
\text { (Bytes) }\end{array}$ & $\begin{array}{l}\text { Nama } \\
\text { File }\end{array}$ & $\begin{array}{c}\text { Size } \\
\text { (Bytes) }\end{array}$ & \\
\hline 1. & $\begin{array}{l}\text { Test1(1). } \\
\text { doc }\end{array}$ & $1,074,688$ & $\begin{array}{l}\text { Test1(1) } \\
\text { doc }\end{array}$ & 1.074 .704 & 24,03087 \\
\hline 2. & $\begin{array}{l}\text { Test1(2). } \\
\text { doc }\end{array}$ & 529.408 & $\begin{array}{l}\text { Test1(2) } \\
\text { doc }\end{array}$ & 529.424 & 11,45275 \\
\hline 3. & $\begin{array}{l}\text { Test1(3). } \\
\text { doc }\end{array}$ & 32.256 & $\begin{array}{l}\text { Test1(3) } \\
\text { dec }\end{array}$ & 32.272 & 0,82725 \\
\hline
\end{tabular}

\begin{tabular}{|c|c|c|c|c|c|}
\hline 4. & $\begin{array}{l}\text { Test1(4). } \\
\text { doc }\end{array}$ & 660.992 & $\begin{array}{l}\text { Test1(4) } \\
\text { doc }\end{array}$ & 661.008 & 13,84363 \\
\hline 5. & $\begin{array}{l}\text { Test1(5). } \\
\text { doc }\end{array}$ & 867.840 & $\begin{array}{l}\text { Test1(5) } \\
\text { doc }\end{array}$ & 867.856 & 17,8745 \\
\hline 6. & $\begin{array}{l}\text { Test2(1). } \\
\text { xls }\end{array}$ & 34.304 & $\begin{array}{l}\text { Test2(1) } \\
\text { xls }\end{array}$ & 34.320 & 0,655875 \\
\hline 7. & $\begin{array}{l}\text { Test2(2). } \\
\text { xls }\end{array}$ & 45.056 & \begin{tabular}{|l} 
Test2(2) \\
xls \\
\end{tabular} & 45.072 & 0,88975 \\
\hline 8. & $\begin{array}{l}\text { Test2(3). } \\
\text { xls }\end{array}$ & 39.936 & \begin{tabular}{|l|} 
Test2(3) \\
.xls
\end{tabular} & 39.952 & 0,952375 \\
\hline 9. & $\begin{array}{l}\text { Test2(4). } \\
\text { xls }\end{array}$ & 36.352 & \begin{tabular}{|l} 
Test2(4) \\
.xls \\
\end{tabular} & 36.368 & 0,749875 \\
\hline 10 & $\begin{array}{l}\text { Test2(5). } \\
\text { xls }\end{array}$ & 41.472 & $\begin{array}{l}\text { Test2(5) } \\
\text {.xls }\end{array}$ & 41.488 & 1,03075 \\
\hline 11 & $\begin{array}{l}\text { Test3(1). } \\
\text { psd }\end{array}$ & 464.484 & $\begin{array}{l}\text { Test3(1) } \\
\text {.psd }\end{array}$ & 464.496 & 9,140625 \\
\hline 12 & $\begin{array}{l}\text { Test3(2). } \\
\text { psd }\end{array}$ & 456.135 & \begin{tabular}{|l} 
Test3(2) \\
.psd \\
\end{tabular} & 456.152 & 8,811625 \\
\hline 13 & $\begin{array}{l}\text { Test3(3). } \\
\text { psd }\end{array}$ & 611.491 & $\begin{array}{l}\text { Test3(3) } \\
\text {.psd }\end{array}$ & 611.504 & 11,9375 \\
\hline 14 & $\begin{array}{l}\text { Test3(4). } \\
\text { psd }\end{array}$ & 874.467 & $\begin{array}{l}\text { Test3(4) } \\
\text {.psd } \\
\end{array}$ & 874.480 & 17,1555 \\
\hline 15 & $\begin{array}{l}\text { Test3(5). } \\
\text { psd }\end{array}$ & 2.964 .970 & $\begin{array}{l}\text { Test3(5) } \\
\text {.psd }\end{array}$ & 2.964 .984 & 58,95275 \\
\hline 16 & $\begin{array}{l}\text { Test4(1). } \\
\text { ppt }\end{array}$ & 1.413 .120 & $\begin{array}{l}\text { Test4(1) } \\
\text {.ppt } \\
\end{array}$ & 1.413 .136 & 29,65537 \\
\hline 17 & $\begin{array}{l}\text { Test4(2). } \\
\text { ppt }\end{array}$ & 861.696 & $\begin{array}{l}\text { Test4(2) } \\
\text {.ppt }\end{array}$ & 861.712 & 16,76513 \\
\hline 18 & $\begin{array}{l}\text { Test4(3). } \\
\text { ppt }\end{array}$ & 808.960 & $\begin{array}{l}\text { Test4(3) } \\
\text {.ppt }\end{array}$ & 808.976 & 15,65588 \\
\hline 19 & $\begin{array}{l}\text { Test4(4). } \\
\text { ppt }\end{array}$ & 751.616 & $\begin{array}{l}\text { Test4(4) } \\
\text {.ppt }\end{array}$ & 751.632 & 14,76563 \\
\hline 20 & $\begin{array}{l}\text { Test4(5). } \\
\text { ppt }\end{array}$ & 582.144 & $\begin{array}{l}\text { Test4(5) } \\
\text {.ppt }\end{array}$ & 582.160 & 11,4835 \\
\hline
\end{tabular}

Tabel 2. Hasil Proses Dekripsi File Algoritma Blowfish

\begin{tabular}{|c|l|c|l|l|c|}
\hline \multirow{2}{*}{ No } & \multicolumn{2}{|c|}{ File Terenkripsi } & \multicolumn{2}{|c|}{$\begin{array}{c}\text { File Asli (Hasil } \\
\text { Dekripsi) }\end{array}$} & \multicolumn{1}{|l}{$\begin{array}{l}\text { Waktu } \\
\text { Proses } \\
\text { (ms) }\end{array}$} \\
\cline { 2 - 5 } & $\begin{array}{l}\text { Nama } \\
\text { File }\end{array}$ & $\begin{array}{c}\text { Size } \\
\text { (Bytes) }\end{array}$ & $\begin{array}{l}\text { Nama } \\
\text { File }\end{array}$ & $\begin{array}{c}\text { Size } \\
\text { (Bytes) }\end{array}$ & \\
\hline 1. & $\begin{array}{l}\text { Test1(1). } \\
\text { doc }\end{array}$ & 1.074 .704 & $\begin{array}{l}\text { Test1(1) } \\
\text { doc }\end{array}$ & $1,074,688$ & 22,48388 \\
\hline 2. & $\begin{array}{l}\text { Test1(2). } \\
\text { doc }\end{array}$ & 529.424 & $\begin{array}{l}\text { Test1(2) } \\
\text {.doc }\end{array}$ & 529.408 & 10,484 \\
\hline 3. & $\begin{array}{l}\text { Test1(3). } \\
\text { doc }\end{array}$ & 32.272 & $\begin{array}{l}\text { Test1(3) } \\
\text { doc }\end{array}$ & 32.256 & 0,7655 \\
\hline 4. & $\begin{array}{l}\text { Test1(4). } \\
\text { doc }\end{array}$ & 661.008 & $\begin{array}{l}\text { Test1(4) } \\
\text {.doc }\end{array}$ & 660.992 & 12,9835 \\
\hline 5. & $\begin{array}{l}\text { Test1(5). } \\
\text { doc }\end{array}$ & 867.856 & $\begin{array}{l}\text { Test1(5) } \\
\text { doc }\end{array}$ & 867.840 & 16,89 \\
\hline 6. & $\begin{array}{l}\text { Test2(1). } \\
\text { xls }\end{array}$ & 34.320 & $\begin{array}{l}\text { Test2(1) } \\
\text { xls }\end{array}$ & 34.304 & 0,79625 \\
\hline 7. & $\begin{array}{l}\text { Test2(2). } \\
\text { xls }\end{array}$ & 45.072 & $\begin{array}{l}\text { Test2(2) } \\
\text { xls }\end{array}$ & 45.056 & 1,0155 \\
\hline 8. & $\begin{array}{l}\text { Test2(3). } \\
\text { xls }\end{array}$ & 39.952 & $\begin{array}{l}\text { Test2(3) } \\
\text { xls }\end{array}$ & 39.936 & 0,905625 \\
\hline 9. & $\begin{array}{l}\text { Test2(4). } \\
\text { xls }\end{array}$ & 36.368 & $\begin{array}{l}\text { Test2(4) } \\
\text { xls }\end{array}$ & 36.352 & 0,859125 \\
\hline 10 & $\begin{array}{l}\text { Test2(5). } \\
\text { xls }\end{array}$ & 41.488 & $\begin{array}{l}\text { Test2(5) } \\
\text {.xls }\end{array}$ & 41.472 & 0,95225 \\
\hline 11 & $\begin{array}{l}\text { Test3(1). } \\
\text { psd }\end{array}$ & 464.496 & $\begin{array}{l}\text { Test3(1) } \\
\text { psd }\end{array}$ & 464.484 & 9,202375 \\
\hline 12 & $\begin{array}{l}\text { Test3(2). } \\
\text { psd }\end{array}$ & 456.152 & $\begin{array}{l}\text { Test3(2) } \\
\text {.psd }\end{array}$ & 456.135 & 8,921375 \\
\hline 13 & $\begin{array}{l}\text { Test3(3). } \\
\text { psd }\end{array}$ & 611.504 & $\begin{array}{l}\text { Test3(3) } \\
\text { psd }\end{array}$ & 611.491 & 12,0935 \\
\hline 14 & $\begin{array}{l}\text { Test3(4). } \\
\text { psd }\end{array}$ & 874.480 \\
\hline 15 & $\begin{array}{l}\text { Test3(5). } \\
\text { psd }\end{array}$ & 2.964 .984 & $\begin{array}{l}\text { Test3(5) } \\
\text { psd }\end{array}$ & 2.964 .970 & 57,82763 \\
\hline
\end{tabular}


Jurnal Pseudocode, Volume 2 Nomor 1, Februari 2015, ISSN 2355 - 5920

\begin{tabular}{|c|l|l|l|l|l|}
\hline 16 & $\begin{array}{l}\text { Test4(1). } \\
\text { ppt }\end{array}$ & 1.413 .136 & $\begin{array}{l}\text { Test4(1) } \\
. p p t\end{array}$ & 1.413 .120 & 28,06225 \\
\hline 17 & $\begin{array}{l}\text { Test4(2). } \\
\text { pt }\end{array}$ & 861.712 & $\begin{array}{l}\text { Test4(2) } \\
. p p t\end{array}$ & 861.696 & 17,04688 \\
\hline 18 & $\begin{array}{l}\text { Test4(3). } \\
\text { ppt }\end{array}$ & 808.976 & $\begin{array}{l}\text { Test4(3) } \\
. p p t\end{array}$ & 808.960 & 15,93713 \\
\hline 19 & $\begin{array}{l}\text { Test4(4). } \\
\text { ppt }\end{array}$ & 751.632 & $\begin{array}{l}\text { Test4(4) } \\
\text {.ppt }\end{array}$ & 751.616 & 14,68713 \\
\hline 20 & $\begin{array}{l}\text { Test4(5). } \\
\text { ppt }\end{array}$ & 582.160 & $\begin{array}{l}\text { Test4(5) } \\
\text {.ppt }\end{array}$ & 582.144 & 11,37412 \\
\hline
\end{tabular}

\begin{tabular}{|l|l|l|l|l|l|}
\hline 19 & $\begin{array}{l}\text { Test4(4). } \\
\text { ppt }\end{array}$ & 751.616 & $\begin{array}{l}\text { Test4(4) } \\
\text { ppt }\end{array}$ & 751.632 & 19,42163 \\
\hline 20 & $\begin{array}{l}\text { Test4(5). } \\
\text { ppt }\end{array}$ & 582.144 & $\begin{array}{l}\text { Test4(5) } \\
\text { ppt }\end{array}$ & 582.160 & 15,15588 \\
\hline
\end{tabular}

Tabel 4. Hasil Proses Dekripsi File Algoritma Twofish

Tabel 3. Hasil Proses Enkripsi File Algoritma Twofish

\begin{tabular}{|c|c|c|c|c|c|}
\hline \multirow[t]{2}{*}{ No } & \multicolumn{2}{|c|}{ File Asli } & \multicolumn{2}{|c|}{ File Terenkripsi } & \multirow{2}{*}{$\begin{array}{c}\text { Waktu } \\
\text { Proses } \\
\text { (ms) }\end{array}$} \\
\hline & $\begin{array}{l}\text { Nama } \\
\text { File }\end{array}$ & $\begin{array}{c}\text { Size } \\
\text { (Bytes) }\end{array}$ & $\begin{array}{c}\text { Nama } \\
\text { File }\end{array}$ & $\begin{array}{c}\text { Size } \\
\text { (Bytes) }\end{array}$ & \\
\hline 1. & $\begin{array}{l}\text { Test1(1). } \\
\text { doc }\end{array}$ & $1,074,688$ & $\begin{array}{l}\text { Test1(1) } \\
\text { doc }\end{array}$ & 1.074 .704 & 31,31162 \\
\hline 2. & $\begin{array}{l}\text { Test1(2). } \\
\text { doc }\end{array}$ & 529.408 & $\begin{array}{l}\text { Test1(2) } \\
\text { doc }\end{array}$ & 529.424 & 13,62425 \\
\hline 3. & $\begin{array}{l}\text { Test1(3). } \\
\text { doc }\end{array}$ & 32.256 & $\begin{array}{l}\text { Test1(3) } \\
\text { doc }\end{array}$ & 32.272 & 0,952625 \\
\hline 4. & $\begin{array}{l}\text { Test1(4). } \\
\text { doc }\end{array}$ & 660.992 & $\begin{array}{l}\text { Test1(4) } \\
\text { doc }\end{array}$ & 661.008 & 17,60913 \\
\hline 5. & $\begin{array}{l}\text { Test1(5). } \\
\text { doc }\end{array}$ & 867.840 & $\begin{array}{l}\text { Test1(5) } \\
\text { doc }\end{array}$ & 867.856 & 22,48388 \\
\hline 6. & $\begin{array}{l}\text { Test2(1). } \\
\text { xls }\end{array}$ & 34.304 & $\begin{array}{l}\text { Test2(1) } \\
\text {.xls }\end{array}$ & 34.320 & 1,06225 \\
\hline 7. & $\begin{array}{l}\text { Test2(2). } \\
\text { xls }\end{array}$ & 45.056 & $\begin{array}{l}\text { Test2(2) } \\
\text { xls }\end{array}$ & 45.072 & 1,281125 \\
\hline 8. & $\begin{array}{l}\text { Test2(3). } \\
\text { xls }\end{array}$ & 39.936 & $\begin{array}{l}\text { Test2(3) } \\
\text {.xls }\end{array}$ & 39.952 & 1,156125 \\
\hline 9. & $\begin{array}{l}\text { Test2(4). } \\
\text { xls }\end{array}$ & 36.352 & $\begin{array}{l}\text { Test2(4) } \\
\text {.xls }\end{array}$ & 36.368 & 1,124875 \\
\hline 10 & $\begin{array}{l}\text { Test2(5). } \\
\text { xls }\end{array}$ & 41.472 & $\begin{array}{l}\text { Test2(5) } \\
\text { xls }\end{array}$ & 41.488 & 1,04675 \\
\hline 11 & $\begin{array}{l}\text { Test3(1). } \\
\text { psd }\end{array}$ & 464.484 & $\begin{array}{l}\text { Test3(1) } \\
\text { psd }\end{array}$ & 464.496 & 12,07813 \\
\hline 12 & $\begin{array}{l}\text { Test3(2). } \\
\text { psd }\end{array}$ & 456.135 & $\begin{array}{l}\text { Test3(2) } \\
\text {.psd }\end{array}$ & 456.152 & 11,90575 \\
\hline 13 & $\begin{array}{l}\text { Test3(3). } \\
\text { psd }\end{array}$ & 611.491 & $\begin{array}{l}\text { Test3(3) } \\
\text { psd }\end{array}$ & 611.504 & 15,78075 \\
\hline 14 & $\begin{array}{l}\text { Test3(4). } \\
\text { psd }\end{array}$ & 874.467 & $\begin{array}{l}\text { Test3(4) } \\
\text {.psd }\end{array}$ & 874.480 & 22,546 \\
\hline 15 & $\begin{array}{l}\text { Test3(5). } \\
\text { psd }\end{array}$ & 2.964 .970 & $\begin{array}{l}\text { Test3(5) } \\
\text {.psd }\end{array}$ & 2.964 .984 & 76,23387 \\
\hline 16 & $\begin{array}{l}\text { Test4(1). } \\
\text { ppt }\end{array}$ & 1.413 .120 & $\begin{array}{l}\text { Test4(1) } \\
\text { ppt }\end{array}$ & 1.413 .136 & 36,437 \\
\hline 17 & $\begin{array}{l}\text { Test4(2). } \\
\text { ppt }\end{array}$ & 861.696 & $\begin{array}{l}\text { Test4(2) } \\
\text { ppt }\end{array}$ & 861.712 & 22,31175 \\
\hline 18 & $\begin{array}{l}\text { Test4(3). } \\
\text { ppt }\end{array}$ & 808.960 & $\begin{array}{l}\text { Test4(3) } \\
\text {.ppt }\end{array}$ & 808.976 & 20,92125 \\
\hline
\end{tabular}

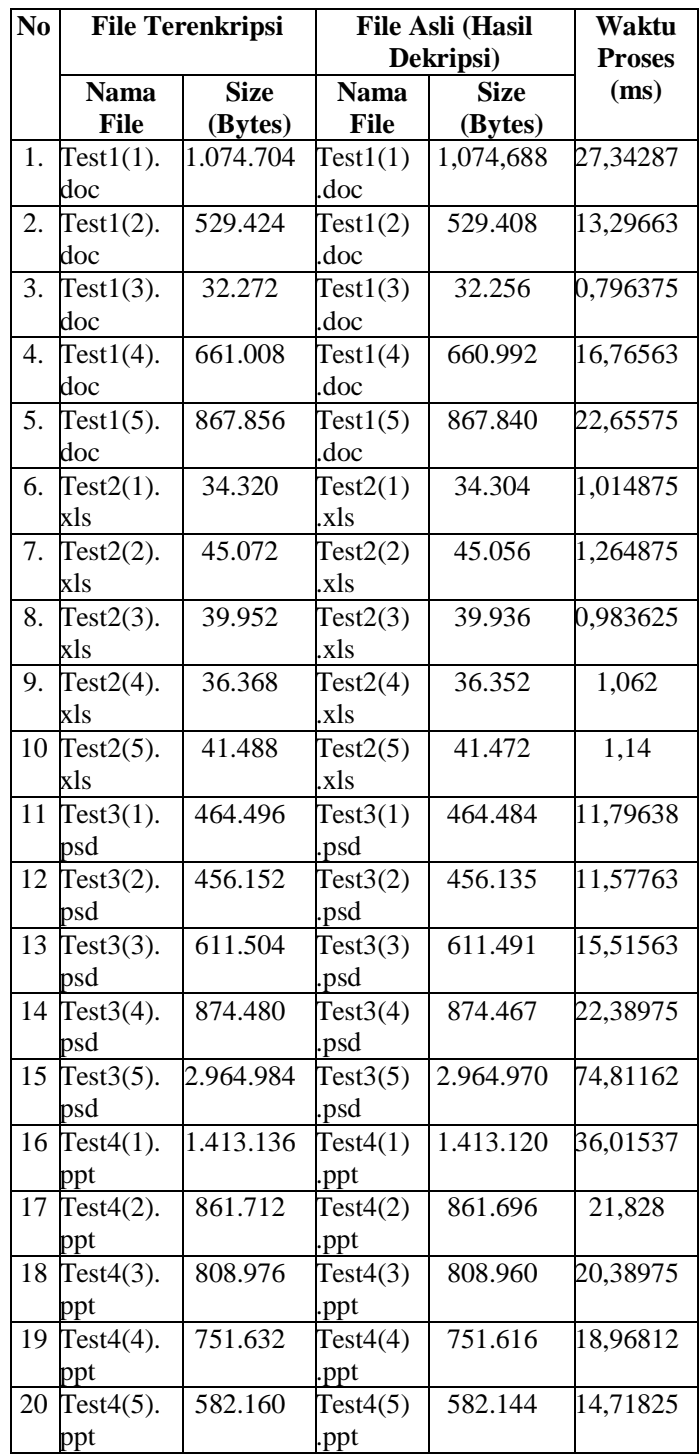

\subsection{Hasil Pengujian}

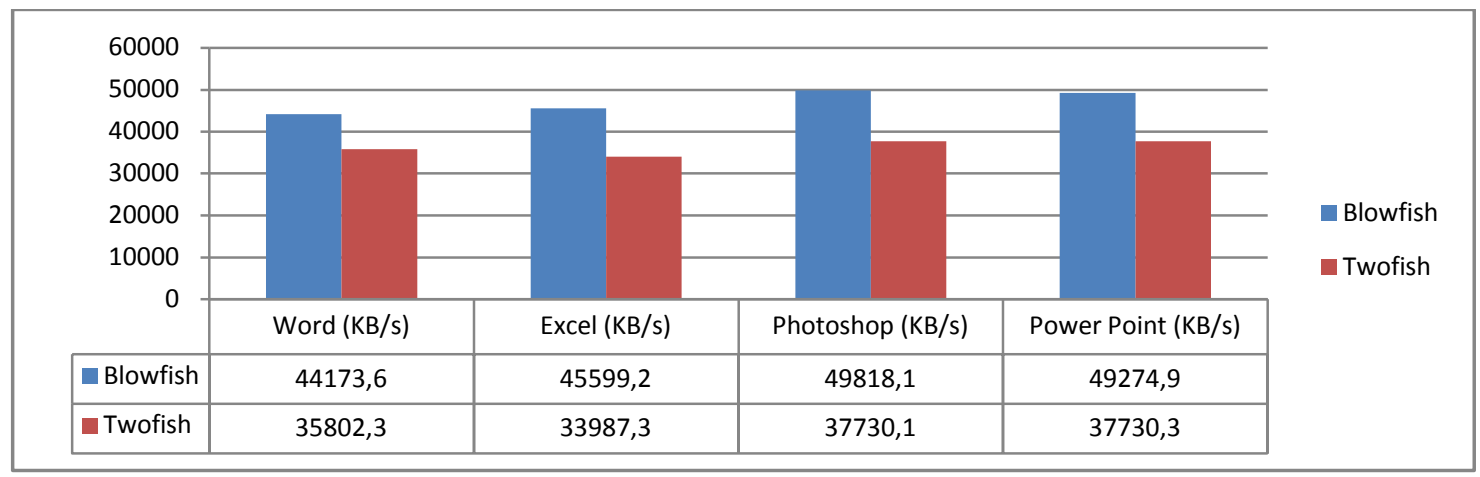

Gambar 6. Grafik Kecepatan Proses Enkripsi Algoritma Blowfish dan Algoritma Twofish 


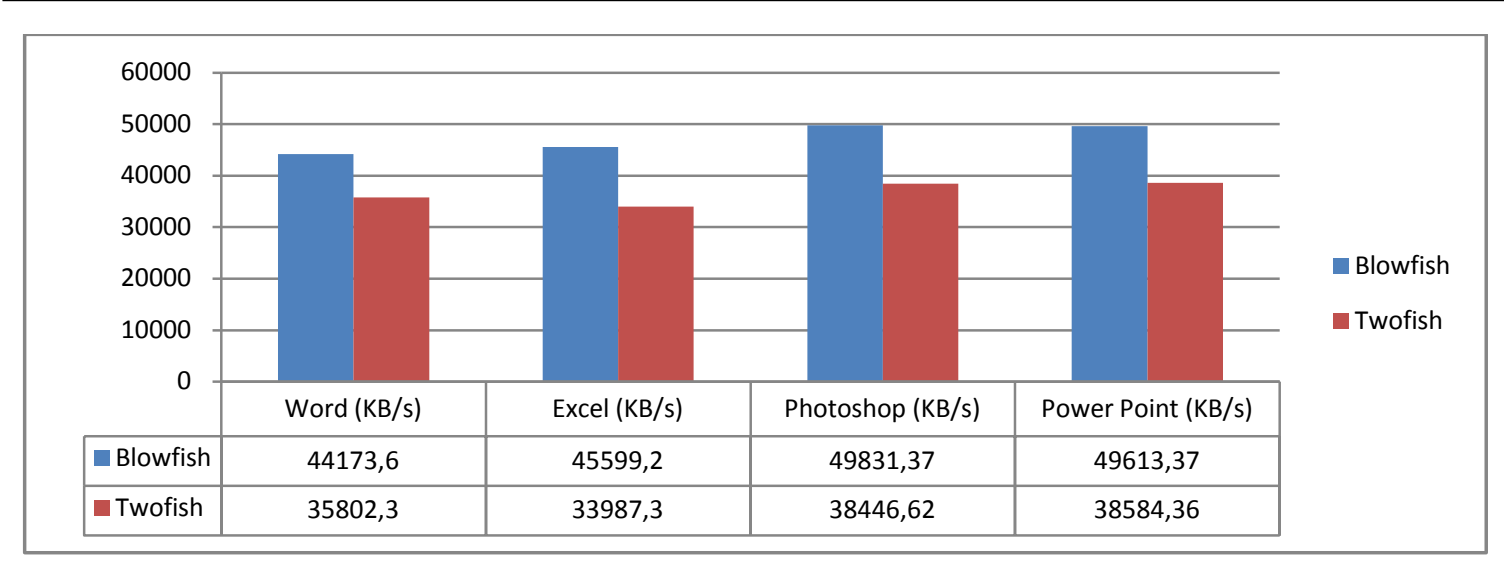

Gambar 7. Grafik Kecepatan Proses Dekripsi Algoritma Blowfish dan Algoritma Twofish

Dari Gambar 7 terlihat bahwa algoritma Blowfish lebih cepat dari algoritma Twofish dalam proses dekripsi

\section{KESIMPULAN}

1. Ditinjau dari besar ukuran file sebelum dan sesudah proses enkripsi dan dekripsi dilakukan antara algoritma Blowfish dan algoritma Twofish, tidak terdapat perbedaan. Ukuran file sebelum dan sesudah proses enkripsi dan dekripsi sama besar.

2. Ditinjau dari kecepatan proses enkripsi antara algoritma Blowfish dan algoritma Twofish, yang tercepat dalam proses enkripsi adalah algoritma Blowfish.

3. Ditinjau dari kecepatan proses dekripsi antara algoritma Blowfish dan algoritma Twofish, yang tercepat dalam proses dekripsi adalah algoritma Blowfish

4. Dilihat dari proses enkripsi, kedua algoritma mampu mengenkripsi file dokumen dengan extention *.doc, *.xls, *.psd, *.ppt. karena file yang telah terenkripsi tidak bisa dibuka.

\section{REFERENSI}

[1] Mulya, M. Bahan Ajar Kriptografi S-1. Fakultas Ilmu Komputer Universitas Sriwijaya. 2008.

[2] Pratiwi, A.E., Lhaksmana, K.M., Rizal, S.J. Implementasi Enkripsi Data dengan Algoritma Blowfish Menggunakan
Java Pada Aplikasi Email. Program Studi Teknik Komputer. Politeknik Telkom Bandung. 2011.

[3] Ratih. Studi dan Implementasi Enkripsi Pengiriman Pesan Suara Menggunakan Algoritma Twofish.. Laporan Tugas Akhir. Program Studi Informatika Sekolah Tinggi Teknik Elektro dan Informatika Institut Teknologi Bandung. 2007.

[4] Setiawan, W. Analisa dan Perbandingan Algoritma Twofish dan Rijndael. Makalah IF3058. Program Studi Teknik Informatika Sekolah Teknik Elektro dan Informatika. Institut Teknologi Bandung. 2010..

[5] Soleh, M.Y. Studi Perbandingan Algoritma KunciSimetris Serpent dan Twofish. Program Studi Teknik Informatika Sekolah Teknik Elektro dan Informatika Institut Teknologi Bandung. 2010.

[6] Syafari, A. Sekilas Tentang Enkripsi Blowfish. IlmuKomputer.Com. 2003. 